\title{
THE IMPACT OF TAX AUDIT AND CORRUPTION PERCEPTION ON TAX EVASION
}

\author{
Ferry Irawan* \\ Department of Tax, Polytechnic of State Finance STAN \\ Adam Siaga Utama \\ Directorate General of Taxes, the Republic of Indonesia
}

\begin{abstract}
This study is aimed to determine the impact of tax audit intensity and perception of corruption on tax evasion activities. Some research that explains the impact of tax audit on tax evasion tends to give a varied result one and another. It is reasonable to assume that there is another factor that simultaneously influences tax evasion. Tax audit and perception of corruption were chosen because of their relevance and intertwine relation in tax authorities function and program, namely tax enforcement and the eradication of corruption. This research is also in line with the challenges faced by many countries in increasing tax compliance. We conduct a panel data regression method with a fixed effect model. We found that tax audit proved insignificant to tax evasion, and perception of corruption positively significant to tax evasion. We conclude that corruption significantly increases tax evasion and undermine the benefit of tax audit
\end{abstract}

Keywords: perception of corruption, tax audit, tax evasion

Received: 17 May 2020

Accepted: 31 July 2021

https://doi.org/10.33736/ijbs.4290.2021

\section{INTRODUCTION}

Tax revenues for many countries are a major source of funding. However, efforts to collect tax revenues have a major obstacle, namely tax compliance issues. Taxes are far from inevitable, albeit a legal obligation. Many countries financially suffer from a lack of tax compliance. International Monetary Fund (IMF) (2015) stated that $60 \%$ of countries in the world only have a tax ratio of $10 \%$ in 1990. That number even increased to $75 \%$ of countries in the world in 2013. A low compliance rate is closely related to tax evasion. Tax evasion is an illegal and intentional act done by the taxpayer to reduce the tax obligation according to the prevailing laws and regulations (Alm, 1999). Tax evasion becomes a major problem because in addition to reducing tax revenues, it also increases government spending in form of tax enforcement to prevent, detect, and overcome the practices and consequences of evasion activities. One of the tax enforcement activities is a tax audit.

Research on tax compliance, tax evasion, and tax audit is abundant. Based on Becker (1968) and Allingham and Sandmo (1972), deterrence theory of taxation explains that audit activities have a positive impact on compliance improvement. In subsequent research, tax audit activities provide a

- Corresponding author: Department of Tax, Polytechnic of State Finance STAN, Address: Jalan Bintaro Utama Sektor V, Bintaro Jaya, Tangerang Selatan, Indonesia; Tel. +62217361653; email: ferry.irawan@pknstan.ac.id 
varied impact on tax compliance. A tax audit may promote both enforced and voluntary compliance (Kirchler et al., 2008; Kogler et al., 2015; Wahl et al., 2010). Tax audit even causes crowding out effect that negatively impacts tax compliance (Gangl et al., 2014; Mendoza et al., 2017; Slemrod et al., 2001). Tax audit could also have no impact on tax compliance (Ariel, 2012; Kleven et al., 2011). Those varied result could mean that enforcement activities could not explain a change in tax evasion by itself, as there is another factor that affects tax evasion decision.

Compliance and evasion can also be motivated by the perception of corruption. The results of research in former Soviet Union countries show that taxpayers tend to evade when corruption exists and the quality of public services is low (Uslaner, 2010). Corruption involving tax authorities is a significant determinant of the company's decision to conduct tax evasion (Alm et al., 2016). IMF (2015) states that corruption by tax authorities in various countries is still a significant concern, both cases of bribery and extortion.

Tax auditor is exposed to a risk of getting bribed or extorted the taxpayer. This research tries to fill the gap in prior research on tax evasion where tax audit and corruption could closely intertwine. Despite some research that tries to explain the subject as mentioned above, we barely know how both tax audit and perception of corruption could simultaneously drive tax evasion decisions. We try to include all of the cross-countries data available on perception index to determine their impact on tax evasion as observed countries have similarities in the tax administration system, which is implementing a self-assessment system, personal income tax, corporate income tax, value-added tax, and periodically conduct a tax audit.

Whilst social culture, tax morale, and other non-economics factor is proved to be significant in determining tax evasion (Richardson, 2006; Tsakumis et al., 2007), tax enforcement activities and eradication of corruption is two factors that tax authorities could effectively control as it became a mandatory program conducted by most tax authorities in the world. This research provides insight for strategic formulation in increasing tax revenue, effective tax audit, and eradication of corruption by explaining the association between low compliance due to tax evasion, the intensity of tax audit, and the perception of corruption at the cross-country level.

\section{LITERATURE REVIEW}

Tax compliance involves accurate reporting of taxable income, subtraction and deductions, correct computation of tax liability, and timely filing of the tax return (Roth et al., 1989). Early theories of tax compliance come from the Economic Theory of Crime by Becker (1968) which explains that tax compliance is based on the rational decision of the taxpayer by weighing the expected utility under conditions of uncertainty of non-compliance will be detected by law enforcement. Subsequent research proved this theory by stating that fines, audits, and tax rates could deter tax evasion (Allingham \& Sandmo, 1972; Srinivasan, 1973; Yitzhaki, 1974).

The existence of taxpayers that remain obedient, despite high utility expectations, indicates the presence of other factors in the tax compliance dimension. Building from behavioral theory, Slippery Slope Framework by Kirchler et al. (2008) explains that compliance is influenced by the level of authority (Power) and the level of trust to the tax authorities, thus divide compliance into enforced, which is coercive, and voluntary compliance, which is legitimate based on trust. Power 
is associated with audit and fines according to Economic Theory of Crime, while trusts are associated with psychological factors such as fairness and social norms. Trust proved to play an important role in tax compliance. Perceptions of distributive justice, procedural justice, retributive justice influence on tax compliance. (Hofmann et al., 2008; Wenzel, 2003). Taxpayers will evade when they perceive others not to carry out their tax obligations, thus creating social norms which dictate that it's perfectly normal to evade tax (Bobek et al., 2007; Cullis \& Lewis, 1997).

Two terms explain taxpayer activity in non-compliance conditions, namely tax evasion and tax avoidance. The principle of legality becomes an important point in distinguishing between evasion and avoidance activities. Tax evasion is an illegal and intentional act done by the taxpayer to reduce the tax obligation according to the prevailing laws and regulations (Alm, 1999). Tax avoidance takes place the facts of the transaction are admitted but they have been arranged in such a way that the resulting tax treatment differs from that intended by the relevant legislation (Kay, 1980, as cited in Slemrod \& Yitzhaki, 2002).

Solving the tax evasion problem focuses on reducing compliance gaps or tax gaps. Andreoni et al. (1998) explain that the indicator of tax evasion is the tax gap, i.e. the difference between the income tax owed by the taxpayer by the amount they paid and report voluntarily on a timely basis. Unfortunately, the tax authority has little to no incentive in estimating the tax gap as a measure of compliance and tax evasion. The underlying constraints, in addition to the absence of measurement standards, are also caused by extensive resource requirements. Therefore, another approach is needed regarding the measurement of tax evasion.

The latest research and surveys use a series of questions to businesses and enterprises to generate a perception index of tax evasion in a country. Mendoza et al. (2017) using data from the Institute for Management Development (IMD) published in the World Competitiveness Yearbook (WCY). Meanwhile, Alm et al. (2016) using data from the World Enterprise Survey from World Bank. The results are likely to produce subjective data, but represent the level of tax evasion in a country through the perception of business people who know the conditions in their respective countries (Mendoza et al., 2017).

Deterrence Theory of Taxation stating that higher levels of tax audits resulted in higher levels of compliance (Allingham \& Sandmo, 1972). The study assumes that taxpayers fully applied expected utility theory in their decision and the probability of tax audits are random. The theory has been heavily criticized. Frey and Feld (2002) suggest that the Allingham and Sandmo models predict too low tax evasion rates and inadequate analysis of econometric parameter estimates. Therefore, the trend of research on tax audits widely began to shift to behavioral research.

Behavioral theory indicates that audit and compliance relationships are non-linear. Research that has been based on taxpayer behaviour turned out to produce diverse conclusions. Audit activities have a positive but insignificant impact on compliance (Alm, 1999; Ariel, 2012; Kleven et al., 2011). Rational taxpayers realize that the intensity of inspection by the tax authorities has a small probability of reaching 100\% (Ariel, 2012). The audit even causing a crowding-out effect that has a negative impact on compliance (Gangl et al., 2014; Mendoza et al., 2017; Slemrod et al., 2001). The overwhelming intensity of the tax audit gives a signal of distrust of the tax authorities to the taxpayer, thus creating a perception that tax audit is too excessive and unfair (Kirchler et al., 2008). 
The perception of distrust and unfairness will lead to resistance which in turn will reduce tax compliance (Hofmann et al., 2008; Kirchler et al., 2008; Wenzel, 2003).

Nevertheless, tax audit remains a significant means of improving tax compliance, in addition to being a compulsory program. Tax audit could simultaneously increase enforced compliance and voluntary compliance (Kirchler et al., 2008; Wahl et al., 2010). Tax audit activity can improve the enforced compliance as the deterrence theory of taxation stated. Tax audit may also increase voluntary compliance because it gives the impression of the efforts of the tax authorities in combating tax evasion thereby increasing the perception of trust and fairness by the taxpayer (Kirchler et al., 2008). Those favourable conditions could be achieved as long as the intensity of the audit is reasonable, on target, and pay attention to compliant taxpayer efforts.

Corruption and tax evasion are two distinct activities, both of which can stand on their own but can correlate and reinforce each other (Alm et al., 2016). Corruption within tax authorities remains a significant problem in many countries, as bribery and extortion have directly affected tax revenues, tax compliance, and the weakness of the tax system itself (IMF, 2015). Extortion is the illegal use of a person's position to forcefully demand payment in return for granting an undue economic advantage (OECD, 2013). Hindriks et al. (1999) describe the various ways in which tax official threatened to set taxes greater than they ought to be, such as rejecting deductible expenses, imposing taxes on tax-free income, or deceiving taxpayers about the characteristics of their income. Bribery involves intentionally promising or giving any advantage to a government official, with the intention that the official acts or refrains from acting concerning their duties (OECD, 2013). In an attempt to bribe the tax official, taxpayers must provide some funds which are hidden in the financial report, which often come from the practice of tax evasion (Acconcia et al., 2003). The possibility of bribery is when tax evasion begins to be detected, i.e. when the tax audit takes place.

Perceptions of corrupt officials increase tax evasion activities as corrupt officials will seek additional income through bribes (Alm et al., 2016). In other words, tax evasion encourages corruption by allowing bribery to the tax official. Corruption also affects the level of trust in the government. Countries with high levels of trust and low levels of corruption tend to have better governance, economic growth, spending, and better legal supremacy (Uslaner, 2004). As explained earlier, the level of trust in government is a major factor of voluntary compliance. It can be indicated that corrupt officials lead to high tax evasion rates as well. Uslaner (2010) found evidence in former Soviet colonies, the high level of bribery to tax officials led to higher tax evasion rates.

Therefore, it is important to build a corruption-free perception within tax authorities. Some ways to achieve that include remuneration (Besley \& Mclaren, 1993), investments in information technology, and continuous budget commitments (IMF, 2015). Chander and Wilde (1992) also stressed the importance of sanctions to taxpayers that prefer to bribe tax official to create effective deterrence.

The earliest research on tax audits and tax compliance can be traced to (Becker, 1968), followed by Allingham and Sandmo (1972), Srinivasan (1973), Yitzhaki (1974). As previously mentioned, those researches constructed deterrence theory of taxation which stated that tax audit, as well as fines and tax rate, has a significant and positive impact on tax compliance. Behavioral research such as Kirchler et al. (2008) and Wahl et al. (2010) conclude that tax audits could increase both enforced and voluntary compliance simultaneously. Research in this scope tends to use more 
experimental research methods and survey. Research that used cross-country analysis such as Richardson (2006) and Tsakumis et al. (2007) does not focus on tax evasion relationships with tax audits, but rather on individual factors, wealth, and cultural dimensions.

Kleven et al. (2011) examine the impact of the audit on tax evasion decisions. The experimental research indicates that taxpayers who must report their tax obligations (self-assessment) tend to be less likely to respond to information about a tax audit unless previously having experience audited by the tax official. Ariel (2012) in his research concluded that the audit is not significant to tax evasion. The study implies that rational taxpayers tend to realize that the intensity of audit by tax authorities is unlikely to reach $100 \%$ because of the low frequency of meetings between tax authorities and taxpayers, and tax authorities do not have sufficient resources to conduct a fullfledge audit that covers all taxpayers.

Slemrod et al. (2001) conclude that audits only have a positive impact on the low and middleincome taxpayer, whilst high-income tax payer's compliance fell considerably. Experimental research by Gangl et al. (2014) shows that supervision in form of audit leads to delayed tax payments and causes a crowding out of intrinsic tax compliance. Mendoza et al. (2017) specifically analyzed the intensity of audit and tax evasion in the cross-countries level. The results show that the audit intensity has a backfiring effect on tax evasion resembling the u-curve.

Notable research on tax evasion and corruption were Chander and Wilde, (1992), Hindriks et al. (1999), and Acconcia et al. (2003) which emphasizes the impact of corruption on tax evasion in the scope of a household. Meanwhile, Besley and McLaren (1993) focus more on the magnitude of tax official's income and its impact on corruption and tax evasion. Research focusing on corporate corruption and tax evasion are by Uslaner (2010). The result indicates that a high perception of corruption has a positive effect on tax evasion, fulfilment of public goods is considered unsatisfactory. Alm et al. (2016) using Business Environment and Enterprise Performance Survey (BEEPS) survey data from World Bank provide a similar result to Uslaner (2010), which stated that the perception of tax official that vulnerable to bribery will increase incentive to evade. Note that most of research in this scope tend to have a similar and consistent result.

As IMF (2015) mentioned that corruption within the revenue administration or tax authority remains a significant concern in many countries. The tax audit is certainly a mandatory program that is intensively carried out by the tax authority in the world. It can be indicated that the intensity of audits and perceptions of corruption will simultaneously influence tax evasion decisions. Various research that has been mentioned, both based on the economic theory of crime and behavioral theory, regarding the impact of audit on compliance and tax evasion tend to be inconclusive because they provide different conclusions. Based on these reasons, it is necessary to use another approach by adding to the determinant of perceptions of corruption in seeing the effect of tax audits on tax evasion.

Prior research focuses primarily on how tax audit or corruption as a single main variable which affects tax evasion decision rather than considers both to simultaneously affect tax evasion. We build the hypothesis based on previous research in the perception of corruption and tax evasion. High perception of corruption has a positive effect on tax evasion level based on Alm et al. (2016) 
and Uslaner (2010). The correlation between corruption and tax evasion is significant because it could reinforce each other and have a devastating effect on honest tax payer's trust.

We hypothesize that tax audit has an insignificant impact on tax evasion based on Alm (1999), Ariel (2012), and Kleven et al. (2011). In presence of corruption, tax official, including tax auditors tend to seek additional income through bribes and extortion. On the other hand, taxpayer will have perceived that a high level of corruption means an opportunity to evade because they could bribe the auditor, rendering tax audits useless. As previously stated, the possibility of bribery is when tax evasion begins to be detected, i.e. when the tax audit takes place. Note that intensity of tax audit in practice is significantly lower than theoretical capacity as tax authorities will always face a resource constrain.

We could summarize our hypothesis as follows:

Hypothesis 1: tax audit intensity has an insignificant impact on tax evasion

Hypothesis 2: perception of corruption has a positive and significant impact on tax evasion

\section{METHODOLOGY}

This research applies the panel data regression method with a fixed effect model on countries that are available in two main publications, World Competitiveness Yearbook, and Tax Administration Comparative Report. Observations were conducted covering the period of 2002 to 2015. We conduct a classical assumption diagnostic test to make sure we have the Best Linear Unbiased Estimated model. The test consists of autocorrelation, multicollinearity, and heteroskedasticity diagnostic. Interpretation of statistical results is conducted to determine independent variables that have a significant impact on the dependent variable based on the hypothesis. Variables used in this research are as follows.

\section{Dependent variable}

The dependent variable in this research is the perception of tax evasion. The tax evasion index is taken from the Rule of Law index of World Competitiveness Yearbook (WCY), publications obtained from World Bank's Worldwide Governance Indicators. This index measures whether tax evasion is a common business practice. Zero value explains that tax evasion is a common activity, while a value of 10 explains that there is no tax evasion activity. The index value is reversed to show that the greatest value represents a high level of tax evasion.

\section{Independent Variable}

\section{a. Tax audit intensity}

Tax audit intensity describes the frequency of activities performed by the tax authorities to determine whether the taxpayer has properly reported tax liabilities in the Tax Return. Measurements of these variables are done based on research Mendoza et al. (2017), the number of tax audits completed for one year, and the number of audits completed for one year divided by the taxpayer population. Because taxpayer population data is not available every year, we use population databases of the nearest year. Tax audit data was gathered from Tax Administration Comparative Report published by the OECD. 


\section{b. Perceptions of Corruption}

We used perceptions of corruption index from Control of Corruption index data from WCY, which indicates that corruption and bribery are common business practice. Index value 0 explains that the level of corruption is very high, while the value of 10 for no corrupt practices. The index value is reversed to show the greatest value represents a high level of corruption perception.

\section{Control Variable}

We included several control variables based on research conducted by Mendoza et al. (2017). These variables are:

\section{a. Fines and Interest Rate}

Based on Allingham and Sandmo (1972), tax fines affect tax compliance. Fines variable measures the maximum percentage a taxpayer should pay when it is convicted of tax evasion. The interest rate variable describes the interest rate on short-term loans. This is because the fines are usually followed by interest sanctions when the payment is due and the interest sanctions tend to follow the loan interest rate. Data related to maximum tax sanctions are taken from TACR, while interestrelated data is taken from the World Bank database.

\section{b. $\quad$ PIT and CIT}

Based on Allingham and Sandmo (1972), tax rates affect tax compliance. Therefore, this research uses control variables personal income tax rate and corporate income tax rate. Data on the tax rate is obtained from the KPMG tax database and OECD database.

\section{c. GDP per capita}

GDP variables control other factors such as welfare, economic growth, and the capacity of government resources that could affect compliance based on Richardson (2006). Data for GDP per capita in US dollars are derived from the IMF World Economic Outlook Database and OECD Database.

\section{d. Trust in government}

Trust in government control the effects of business perceptions related to the fulfillment of public goods and the effectiveness of government policy (Mendoza et al., 2017). We used the government's effectiveness index, which value of 0 indicates that government policy is ineffective up to 10 which explains that government policy is very effective. Data on this index is obtained from WCY.

\section{Model Specification}

Based on the hypothesis and variables mentioned in the previous section, the research model in this research is as follows:

$$
\begin{gathered}
\text { TEVA }_{i, t+1}=c_{0 i, t}+\beta_{1} \text { Audit }_{i, t}+\beta_{2} \text { Corrupt }_{i, t+1}+\beta_{4} \text { Int }_{i, t}+\beta_{5} \text { PIT }_{i, t}+\beta_{6} \text { CIT }_{i, t} \\
+\beta_{7} \text { GDP }_{i, t}+\beta_{8} \text { Trust }_{i, t+1}+\text { Year Dummy }+\varepsilon_{i t}
\end{gathered}
$$

\section{Description:}

TEVA : Tax Evasion Index; 


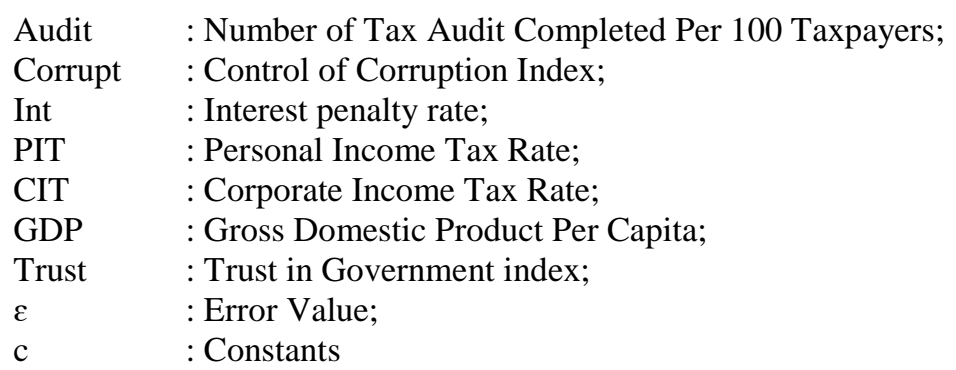

Tax evasion index and trust in government are transformed into lead variables. This means the number of audits completed for year $t$ is analyzed with perceptions of tax evasion for year $t+1$. Transformation is done to get a perception of tax evasion which is influenced by audit activities in the previous year. This is because the data collection by IMD for year $t$ is indirectly captures data for part of year $t+1$ as it did from January to April in year $t+1$. We apply the same method for the control of the corruption variables. We use dummies for each of the years in our data to control for time effect which captured the influence of aggregate time series trend.

We test this baseline model through some robustness test based on Mendoza et al. (2017) as a means of proving the resilience and consistency of the baseline model. Note that the fines variable is not included in the baseline model because the availability of the data is much less than other control variables. Based on these conditions, the hot deck imputation of missing values makes the variable has stationary data that could affect the robustness of the baseline model. The robustness test is done through four stages and categorized into four models, namely model 2 to model 5 . The variables used as robustness tests are summarized in Table 1.

Table 1: Variable used in models 1 through 5

\begin{tabular}{cccccc}
\hline \hline Variable & $\begin{array}{c}\text { Model 1 } \\
\text { (Baseline) }\end{array}$ & Model 2 & Model 3 & Model 4 & Model 5 \\
\hline Tax Evasion & D & D & D & D & D \\
Perception on Corruption & I & I & I & I & I \\
Total Audit Completed & & I & & & \\
Number of Audit & & & I (Without & I \\
Completed Per 100 Tax & I & & Outliers) & \\
Payer & & C & C & C & C \\
GDP Per Capita & C & C & C & C & C \\
Trust in Government & C & & C & & \\
Fines (imputed) & & C & C & C & \\
Interest Rate (imputed) & C & C & C & C & \\
PIT rate (imputed) & C & C & C & C & \\
CIT rate (imputed) & C & & & &
\end{tabular}

Description:

D: Dependent Variable; I: Independent Variable; C: Control Variable

Source: processed by authors 
Model 2 replaces the Number of Audits completed per 100 taxpayers with a total of audits completed. This is conducted to anticipate the possibility of the imputation of taxpayer's population influence on baseline model's goodness of fit and to assess which information is more captured by enterprises in the tax evasion. Model 3 seeks to see the effect of eliminating fines control variables on the robustness of the baseline model. Model 4 excludes outliers by reducing observations that have an audit intensity above $100 \%$ and below $0.1 \%$. Model 5 attempts to test the impact of imputation on variables with missing values by excluding said variables.

\section{RESULTS AND DISCUSSION}

\section{Data Description}

Data used in this research is selected based on the slices between the countries whose data are available on TACR and WCY publications. We exclude countries with less than five years of available tax audit data. This is done to avoid time series data with too many missing values. Table 2 shows a list of 47 countries that were used as research objects based on predetermined criteria. In assisting the uniformity of the interpretation of the research results, we confirmed that observed countries have similarities in the tax administration system, which apply self-assessment system, have a personal income tax, corporate income tax, and value-added tax based on Tax Guides And Highlights ( Deloitte International Tax Source, 2017) and worldwide tax summaries (PwC, 2014).

Table 2: Countries Included in Observation

\begin{tabular}{lllll}
\hline Argentina & Croatia & India & Mexico & Slovenia \\
Australia & Czech Rep. & Indonesia & Netherlands & South Africa \\
Austria & Denmark & Ireland & New Zealand & Spain \\
Belgium & Estonia & Israel & Norway & Sweden \\
Brazil & Finland & Italy & Poland & Switzerland \\
Bulgaria & France & Japan & Portugal & USA \\
Canada & Germany & Korea & Romania & United Kingdom \\
Chile & Greece & Lithuania & Russia & \\
China & HongKong & Luxembourg & Singapore & \\
Colombia & Hungary & Malaysia & Slovak Rep. & \\
\hline
\end{tabular}

Source: processed by authors

Data on tax evasion, Tax Audit Completed, GDP per capita, Trust in Government, PIT, CIT, Fines, and interest rate from 2002 until 2013 are publicly available from Mendoza et al. (2017) on www.sciencedirect.com webpage under CC BY NC 3.0 license. Updating the data is required with the latest publications to anticipate the change of data of the used variable. We add the amount of data on each variable related to the increase of observation year and the addition of independent variable data of perception of corruption index.

Taxpayer population, fines, and interest rate have several missing values. The missing values of the control variable will be solved by the imputation of data with the Hot Deck method, which is done by assigning the value of the nearest last known observation (Schoier, 2008). Meanwhile, we do not impute population values into the Number of Tax Audit Completed Per 100 Taxpayers as 
it's an independent variable. We transform Total audit, fines, interest rates, and GDP per capita to its natural logarithm as it has an unsymmetrical data distribution.

We provide descriptive statistical analysis to give an insight from tabulated data which consists of mean, maximum, minimum, and standard deviation. Table 3 shows the descriptive statistical results.

Table 3: Descriptive Statistic

\begin{tabular}{lccccc}
\hline \multicolumn{1}{c}{ Variable } & Obs & Mean & $\begin{array}{c}\text { Std. } \\
\text { Dev. }\end{array}$ & Min & Max \\
\hline Tax Evasion & 459 & 5.39 & 1.7 & 0.98 & 9.3 \\
Perception on Corruption & 459 & 5.25 & 2.61 & 0.59 & 9.78 \\
Total Audit Completed & 459 & 0.8 & 1.52 & 0.002 & 12 \\
Number of Audits Completed Per 100 Tax & 459 & 6.56 & 12.09 & 0.01 & 107.69 \\
Payer & 459 & 28.5 & 14.53 & 2.91 & 81.1 \\
GDP Per Capita & 459 & 4.56 & 1.59 & 0.76 & 8.49 \\
Trust in Government & 459 & 1.24 & 1.56 & 0 & 10 \\
Fines (imputed) & 459 & 4.9 & 6.38 & 0.02 & 67.08 \\
Interest Rate (imputed) & 459 & 36.76 & 11.83 & 0.1 & 59 \\
PIT rate (imputed) & 459 & 26.56 & 7.19 & 10 & 40.87 \\
CIT Rate (imputed) & & & &
\end{tabular}

Source: processed by authors

In sum, the average tax evasion index for 459 observations is 5.39. The average perception of corruption for 459 observations is 5.25 . We can highlight that on average, only $6.56 \%$ of the 100 taxpayers were audited per year in a country. The number of audit for 459 observations has an average of 800 thousand audits in a year. The maximum number of audit is 12 million audits. This amount was reached by the United States in 2004. The minimum number of audits in a year is 2000 audits. This amount was reached by Estonia in 2008. Note that the statistics of the four control variables are similar to the value after the Hot Deck imputation, both on average and the distribution of data.

We run Chow Test and Haussman Test to determine the panel data regression method. Chow test result shows that Prob > F value for all five types of researches model is 0 . While Haussman test result shows Prob>chi2 value for all five types of researches models are below $\alpha(0.05)$. Both of the results favor the fixed-effect model rather than pooled least square or random-effect model.

Table 4: Chow Test and Haussman Test Result

\begin{tabular}{ccc}
\hline \hline \multirow{2}{*}{ Research Model } & Chow Test & Haussman Test \\
\cline { 2 - 3 } Model 1 (Baseline) & Prob > F & Prob > chi2 \\
Model 2 & 0 & 0.0001 \\
Model 3 & 0 & 0.0001 \\
Model 4 & 0 & 0 \\
Model 5 & 0 & 0 \\
\hline \hline
\end{tabular}


The regression results of fixed effect panel data analysis with year dummies and standard error clustering based on observed countries are reported in table 5. We added a-robust clustered commands to deal with heteroscedasticity and autocorrelation problems. This shows that the test is done by using the standard error clustering method to get the variance accuracy of the statistical estimator that is resistant to heteroscedasticity and autocorrelation. Justification of the method proposed by Williams (2000) who states that between-cluster variance estimator does not experience a bias problem in regression analysis, especially on cluster-correlated data.

Table 5: Regression Results

\begin{tabular}{|c|c|c|c|c|c|c|c|c|c|c|}
\hline \multirow[t]{2}{*}{ Variable } & \multicolumn{2}{|c|}{$\begin{array}{l}\text { Model } 1 \\
\text { (Baseline) }\end{array}$} & \multicolumn{2}{|c|}{ Model 2} & \multicolumn{2}{|c|}{ Model 3} & \multicolumn{2}{|c|}{ Model 4} & \multicolumn{2}{|c|}{ Model 5} \\
\hline & $\begin{array}{l}\text { Prob } \\
(\mathrm{t})\end{array}$ & Coeff & $\begin{array}{l}\text { Prob } \\
(\mathrm{t})\end{array}$ & Coeff & $\begin{array}{l}\text { Prob } \\
(\mathrm{t})\end{array}$ & Coeff & $\begin{array}{l}\text { Prob } \\
(\mathrm{t})\end{array}$ & Coeff & $\begin{array}{l}\text { Prob } \\
(\mathrm{t})\end{array}$ & Coeff \\
\hline $\begin{array}{l}\text { Perception of } \\
\text { Corruption }\end{array}$ & 0.002 & 0.351 & 0.003 & 0.350 & 0.003 & 0.0350 & 0.001 & 0.384 & 0.001 & 0.356 \\
\hline $\begin{array}{l}\text { Total Audit } \\
\text { Competed }\end{array}$ & & & 0.223 & 0.0375 & & & & & & \\
\hline $\begin{array}{l}\text { Number of } \\
\text { Audit } \\
\text { completed per } \\
100 \text { tax }\end{array}$ & 0.159 & 0.044 & & & 0.160 & 0.443 & 0.116 & 0.056 & 0.254 & 0.312 \\
\hline $\begin{array}{l}\text { GDP } \\
\text { capita }\end{array}$ & 0.430 & -0.235 & 0.417 & -0.276 & 0.431 & -0.233 & 0.496 & 0.014 & 0.276 & 0. \\
\hline $\begin{array}{l}\text { Trust in } \\
\text { Government }\end{array}$ & 0.013 & -0.237 & 0.013 & -0.238 & 0.013 & -0.238 & 0.021 & $0 . \overline{220}$ & 0.013 & $0 . \overline{235}$ \\
\hline $\begin{array}{l}\text { Interest Rate } \\
\text { (imputed) }\end{array}$ & 0.179 & -0.102 & 0.177 & -0.105 & 0.181 & -0.102 & 0.169 & $\begin{array}{c}- \\
0.105\end{array}$ & & \\
\hline $\begin{array}{l}\text { PIC rate } \\
\text { (imputed) }\end{array}$ & 0.398 & 0.040 & 0.415 & 0.003 & 0.399 & 0.004 & 0.367 & 0.005 & & \\
\hline $\begin{array}{l}\text { CIT rate } \\
\text { (imputed) }\end{array}$ & 0.233 & -0.234 & 0.234 & -0.023 & 0.234 & -0.023 & 0.306 & $\begin{array}{c}- \\
0.017\end{array}$ & & \\
\hline $\begin{array}{l}\text { Fines } \\
\text { (imputed) }\end{array}$ & & & & & 0.377 & 0.013 & & & & \\
\hline R-Squared & & 522 & & 531 & & 513 & & & & 27 \\
\hline Prob (F) & & 000 & & 00 & & 000 & & & & 00 \\
\hline Constant & 7.4 & 338 & & 143 & 7.4 & 756 & & 704 & 10 . & 983 \\
\hline
\end{tabular}

Source: processed by authors

The goodness of fit model can be seen through the coefficient of determination from R-Squared values. Baseline R-Squared values are equal to 0.6522. This means that independent variables and control variables for the baseline model can explain the $65.22 \%$ variance of the dependent variable. We conclude that independent variables used in the model can adequately explain the dependent variable. All independent variables simultaneously have a significant effect on the dependent variable as seen on the probability of F-statistic value in the baseline model which is equal to 0.0000 .

Pair t-test result shows that perception of corruption has a probability of t-statistic value smaller than $\alpha(0.05)$ with a positive coefficient, which means perception of corruption has a significant 
positive effect on tax evasion. The Number of Tax Audit Completed Per 100 Taxpayers has a positive coefficient and probability of the t-statistic value of 0.159 which is greater than $\alpha$. It means that Number of tax audit per 100 taxpayers have a positive but insignificant effect on tax evasion. From the test result, we can conclude that this research hypothesis proved to be true.

Note that model 2 to model 5 follow the same pattern of results as the baseline model. Using percentage of nominal value for measuring the intensity of tax audit provides the same robust result. Likewise, for imputation of data and outlier's removal, the results of the goodness of fit, F test, and t-test yield the same result. Therefore, the baseline model used as the basis in concluding the research hypothesis has an adequate level of resilience and consistency.

\section{Discussion}

The intensity of tax audit in this research proved to have an insignificant effect on tax evasion activities. These results are consistent even though the test model is altered according to criteria that may disrupt the robustness of the research model. Previous research supporting the results of this study was Kleven et al. (2011) and Ariel (2012) which stating that audit activities have an insignificant effect on tax evasion.

Increasing audit activities does not necessarily better. Taxpayers tend to be less responsive to information on audit activities conducted by tax authorities. Rational taxpayers tend to realize that the intensity of inspection by the tax authorities has a small probability of reaching $100 \%$. The results of descriptive analysis prove that on average, only $6.5 \%$ of taxpayers are audited. This is because of the low frequency of meetings between tax authorities and taxpayers and the cliché problem, the resources of tax authorities are not sufficient enough to conduct tax audits that include all taxpayers.

Our findings confirm previous research from Hindriks et al. (1999), Chander and Wilde (1992), Acconcia et al. (2003), Uslaner (2010), and Alm et al. (2016), which state that corruption increases tax evasion. Acts of corruption in the form of extortion and fraud, especially those committed by unscrupulous tax officials render internal and external controls useless. This condition leads to an increase in tax evasion, especially when tax knowledge and willingness to report from taxpayer themselves is low. The motivation to enrich own wealth by tax official could also be indicated to effects the high tax evasion activities.

Taxpayers may perceive that tax official is vulnerable to bribe will prefer to report taxes lower than they should. This can happen because activities that could detect tax evasion, such as tax audits, can easily be manipulated by giving bribery. Therefore, it can be concluded that the effect of corrupt actions greatly influences the taxpayer's decision to conduct tax evasion. Alm et al. (2016) even state that tax evasion will not happen at all if there is no corrupt official.

Conversely, low levels of corruption will reduce tax evasion. Low perception of corruption could mean that the taxpayer perceives the tax audit performed on high integrity and professionalism under the prevailing regulations so that the possibility of tax evasion will be effectively detected. Corruption may affect tax evasion by affecting trust. Tax officials that are perceived to be free from corruption will increase trust in the tax authorities. A high trust will increase the legitimate power of the tax authorities, in which tax audits will be seen as constitutional and equitable actions resulting in the tax-abiding social norms. 
In sum, it could be concluded that corruption can greatly increasing tax evasion activities and reduce any benefits caused by tax enforcement activities, including tax audits. In addition, if we look at the results of statistical tests of trust in government control variable, which represent the perceptions related to public goods fulfillment and transparency by the government, have a significant influence in reducing tax evasion. This indicates that controlling voluntary compliance is more appropriate with meeting the needs of public goods compared to increasing the number of audits.

The implications of the research are expected to answer the problems mentioned in Current Challenges in Revenue Mobilization: Improving Tax Compliance by the IMF (2015), i.e. low compliance due to tax evasion and corrupt practices that still occur within the tax authority in various countries. Audit as one of the tax enforcement activities is an activity that does not affect tax compliance. However, a tax authority remains obliged to provide specific resources allocations to audit activities, especially when the tax administration system continues towards self-assessment. Therefore, the government should put more effort on eradicating corrupt practices within tax administration while continuing to deliver public goods and maintain its transparency.

Maximizing the result of tax audits requires a complex strategy, in addition to resources constraints. Biber (2010) argues that focusing on high-risk areas, appropriate sanctions, and publication of yearly audit themes, plans, and outcomes of the tax audit program play an important role in managing tax compliance. Risk analysis, sanctions, and publications are important to assure to taxpayers that tax audits are fair and target taxpayers appropriately. Therefore, the high intensity of audit as a tax enforcement activity does not affect the optimization of taxation policies to reduce tax evasion. Optimal policies could come from changes in a routine or mandatory tax audit that tend to be a comprehensive audit which uses a lot of time and resources, to focus on issue-oriented audit through risk analysis and publication of theme, plans, and audit results, thus providing resource space for other non-enforcement policies that can promote voluntary compliance.

The next implication is the existence of other determinants that can inhibit the effect of the tax audits. Corruption, especially those involving unscrupulous tax officials, not only affects shortterm compliance but further on long-term effects due to erosion of public trust. Significant influence on tax evasion indicates that to escape from corruption to improve compliance requires tremendous effort.

The literature on combating corruption, both design, strategy, and implementation, varies considerably. The eradication of corruption tends to involve cultural reforms and social norms whose implementation differs across countries. But some of the underlying things could be summarized into four parts, namely transparency, law enforcement, economic policy reform, and institutional strengthening (IMF, 2016).

Tax authorities could also provide greater focus on improving internal and external controls in efforts to eradicate corruption. This can be done by closing the gap of corruption, such as investing in better information systems and an adequate whistleblowing channel to improve compliance and reduce tax evasion. In addition, the tax authorities may increase the proportion of rules on withholding taxes and third-party reporting such as prepopulated tax returns that are sustained by a secure and robust information system. 


\section{CONCLUSION}

Based on the fixed effect panel data regression results of 47 countries from 2002 to 2015 , it could be concluded that the intensity of audit has an insignificant effect on tax evasion. Some of the factors that can lead to this are indications that taxpayers who must report their tax obligations (self-assessment) tend to be less likely to respond to information about the audit. Another factor is that rational taxpayers tend to be aware that the intensity of audit by tax authorities is less likely to reach $100 \%$ because of the low frequency of meetings between tax authorities and taxpayers, in addition to the resources owned by the tax authorities are insufficient to examine all taxpayers.

Perception of corruption proved to have a negatively significant impact on tax evasion. Some of the factors underlying the result include corruption renders internal control and external controls systems useless, and reduces trust in the tax authorities, thus reduce voluntary compliance. The significant impact from corruption index could also indicate that to eradicate corrupt practice within tax administration needs a tremendous amount of effort.

The conclusion that can be given according to the research result is that tax evasion will not happen if the government is spared from corrupt practices. Although in theory, tax audits can reduce tax evasion, corrupt practices can foster tax evasion practices and render any benefits incurred by tax enforcement activities including tax audits to be insignificant. Tax authorities should bolster the area that is vulnerable to corruption activities with an increase in transparency, law enforcement, economic policy reform, and institutional strengthening. Meanwhile, focus on issue-oriented audit through risk analysis and publication of theme, plans, and audit results, and appropriate sanctions. By making an efficient tax audit strategy, tax authorities could provide a space in resources for other non-enforcement policies that can promote voluntary compliance, thus reducing tax evasion.

\section{ACKNOWLEDGEMENT}

We would like to thank our colleagues at Polytechnic of State Finance STAN and the Directorate General of Taxes of the Republic of Indonesia for their support.

\section{REFERENCES}

Acconcia, A., Amato, M. D., \& Martina, R. (2003). Corruption and Tax Evasion with Competitive Bribes. Centre for Studies in Economics and Finance (CSEF) Working Paper No. 112.

Allingham, M. G., \& Sandmo, A. (1972). Income tax evasion: a theoretical analysis. Journal of Public Economics, 1(3-4), 323-338. https://doi.org/10.1016/0047-2727(72)90010-2

Alm, J. (1999). Tax compliance and administration. Public Administration and Public Policy, 72, 741-768.

Alm, J., Martinez-Vazquez, J., \& McClellan, C. (2016). Corruption and firm tax evasion. Journal of Economic Behavior and Organization, 124, 146-163. https://doi.org/10.1016/j.jebo.2015.10.006

Andreoni, J., Erard, B., \& Feinstein, J. (1998). Tax compliance. Journal of Economic Literature, $36(2), 818-860$.

Ariel, B. (2012). Deterrence and moral persuasion effects on corporate tax compliance: Findings 
from a randomized controlled trial. Criminology, 50(1), 27-69. https://doi.org/10.1111/j.1745-9125.2011.00256.x

Becker, G. S. (1968). Crime and Punishment: An Economic Approach. Journal of Political Economy, 76(2), 169-217. https://doi.org/10.1086/259394

Besley, T., \& Mclaren, J. (1993). Taxes and Bribery: the Role of Wage Incentives. The Economic Journal, 103(416), 119-141. https://doi.org/10.2307/2234340

Biber, E. (2010). Revenue Administration: Taxpayer Audit - Development of Effective Plans. International Monetary Fund. https://blog-pfm.imf.org/files/fad-technical-manual-11.pdf

Bobek, D. D., Roberts, R. W., \& Sweeney, J. T. (2007). The social norms of tax compliance: Evidence from Australia, Singapore, and the United States. Journal of Business Ethics, 74(1), 49-64.

Chander, P., \& Wilde, L. (1992). Corruption in tax administration. Journal of Public Economics, 49(3), 333-349. https://doi.org/10.1016/0047-2727(92)90072-N

Cullis, J. G., \& Lewis, A. (1997). Why people pay taxes: From a conventional economic model to a model of social convention. Journal of Economic Psychology, 18(2), 305-321.

Deloitte International Tax Source. (2017). Tax Guides And Highlights. Deloitte International Tax Source (DITS) Online Database. https://dits.deloitte.com/\#TaxGuides

Frey, B. S., \& Feld, L. P. (2002). Deterrence and morale in taxation: An empirical analysis.CESIfo Working Paper No. 760. https://www.ifo.de/DocDL/760.pdf

Gangl, K., Torgler, B., Kirchler, E., \& Hofmann, E. (2014). Effects of supervision on tax compliance: Evidence from a field experiment in Austria. Economics Letters, 123(3), 37382. https://doi.org/10.1016/j.econlet.2014.03.027

Hindriks, J., Keen, M., \& Muthoo, A. (1999). Corruption, extortion and evasion. Journal of Public Economics, 74(3), 395-430. https://doi.org/10.1016/S0047-2727(99)00030-4

Hofmann, E., Hoelzl, E., \& Kirchler, E. (2008). Preconditions of voluntary tax compliance: Knowledge and evaluation of taxation, norms, fairness, and motivation to cooperate. Journal of Psychology, 216(4), 209-217. https://doi.org/10.1027/0044-3409.216.4.209

Institute of Management Development. (2017). IMD World Competitiveness Yearbook 2017. https://www.otp.go.th/uploads/tiny_uploads/PDF/2560-08/IMDReport/IMDWorld CompetitivenessYearbook2017/IMD_World_Competitiveness_Yearbook_2017.pdf

International Monetary Fund. (2015). Current Challenges in Revenue Mobilization: Improving Tax Compliance. https://www.imf.org/external/np/pp/eng/2015/020215a.pdf

International Monetary Fund. (2016). Corruption: Costs and Mitigating Strategies. https://www.imf.org/-/media/Websites/IMF/imported-full-text-pdf/external/pubs/ft/sdn/ 2016/_sdn1605.ashx

Kirchler, E., Hoelzl, E., \& Wahl, I. (2008). Enforced versus voluntary tax compliance: The "slippery slope" framework. Journal of Economic Psychology, 29(2), 210-225. https://doi.org/10.1016/j.joep.2007.05.004

Kleven, H. J., Knudsen, M. B., Kreiner, C. T., Pedersen, S., \& Saez, E. (2011). Unwilling or Unable to Cheat? Evidence From a Tax Audit Experiment in Denmark. Econometrica, 79(3), 651692.

Kogler, C., Muehlbacher, S., \& Kirchler, E. (2015). Testing the "slippery slope framework" among self-employed taxpayers. Economics of Governance, 16(2), 125-142. https://doi.org/10.1007/s10101-015-0158-9

Mendoza, J. P., Wielhouwer, J. L., \& Kirchler, E. (2017). The backfiring effect of auditing on tax compliance. Journal of Economic Psychology, 62(July), 284-294. https://doi.org/10.1016/j.joep.2017.07.007 
Organisation for Economic Co-operation Development. (OECD) (2013). Bribery and Corruption Awareness Handbook for Tax Examiners and Tax Auditors. https://doi.org/10.1787/9789264205376-en.

PricewaterhouseCoopers, L. L. P. (PwC) (2014). Worldwide Tax Summaries -Corporate Taxes 2014/15. https://www.pwc.com/gx/en/tax/corporate-tax/worldwide-tax-summaries/assets/ pwc-worldwide-tax-summaries-corporate-2014-15.pdf

Richardson, G. (2006). Determinants of tax evasion: A cross-country investigation. Journal of International Accounting, Auditing and Taxation, 15(2), 150-169. https://doi.org/10.1016/j.intaccaudtax.2006.08.005

Roth, J. A., Scholz, J. T., \& Witte, A. D. (Eds.). (1989). Taxpayer Compliance, Volume 1: An Agenda for Research. University of Pennsylvania Press. http://www.jstor.org/stable/j.ctv512x08.15

Schoier, G. (2008). On partial nonresponse situations: the hot deck imputation method. https://www.stat.fi/isi99/proceedings/arkisto/varasto/scho0502.pdf

Slemrod, J., Blumenthal, M., \& Christian, C. (2001). Taxpayer response to an increased probability of audit: Evidence from a controlled experiment in Minnesota. Journal of Public Economics, 79(3), 455-483. https://doi.org/10.1016/S0047-2727(99)00107-3

Slemrod, J., \& Yitzhaki, S. (2002). Tax Avoidance, Evasion, And Administration. Handbooks in Economics, 3, 1423-1470. https://doi.org/10.1016/S1573-4420(02)80026-X

Srinivasan, T. N. (1973). Tax evasion: A model. Journal of Public Economics, 2(4), 339-346.

Tsakumis, G. T., Curatola, A. P., \& Porcano, T. M. (2007). The relation between national cultural dimensions and tax evasion. Journal of International Accounting, Auditing and Taxation, 16(2), 131-147. https://doi.org/10.1016/j.intaccaudtax.2007.06.004

Uslaner, E. M. (2004). Trust and Corruption. The New Institutional Economics of Corruption, 76.

Uslaner, E. M. (2010). Tax evasion, corruption, and the social contract in transition. Developing Alternative Frameworks for Explaining Tax Compliance, 9780203851616, 174-190. https://doi.org/10.4324/9780203851616

Wahl, I., Kastlunger, B., \& Kirchler, E. (2010). Trust in authorities and power to enforce tax compliance: An empirical analysis of the "slippery slope framework." Law and Policy, 32(4), 383-406. https://doi.org/10.1111/j.1467-9930.2010.00327.x

Wenzel, M. (2003). Tax compliance and the psychology of justice: Mapping the field. Taxing Democracy, 41-70.

Williams, R. L. (2000). A note on robust variance estimation for cluster-correlated data. Biometrics, $56(2), 645-646$.

Yitzhaki, S. (1974). Income tax evasion: A theoretical analysis. Journal of Public Economics, 3(2), 201-202. 